\title{
Emergency medicine airway leads: a rapid response distributed educational model for emergency department COVID-19 airway management
}

\author{
Adam Harris $^{1} \cdot$ Lorri Beatty $^{1} \cdot$ Nicholas Sowers $^{1} \cdot$ Sam G. Campbell ${ }^{1} \cdot$ David Petrie $^{1} \cdot$ David Hung $^{2} \cdot$ George Kovacs $^{1}$
}

Received: 22 June 2020 / Accepted: 21 October 2020 / Published online: 4 January 2021

(c) Canadian Association of Emergency Physicians (CAEP)/ Association Canadienne de Médecine d'Urgence (ACMU) 2021

\begin{abstract}
With the first case of COVID-19 confirmed in Canada in early 2020, our country joined in the fight against a novel pathogen in a global pandemic. The stress of uncertainty and practice change was most apparent in the emergency department when it came to managing known or suspected COVID-19 patients requiring airway management. Recognizing the need for a coordinated approach, a province wide rapid response distributed model of continuing professional development for airway management was developed utilizing Airway Leads to help prepare front-line medical personnel providing airway management for these patients. Airway Leads worked with local physicians to deliver consistent, high quality airway education across the province during the initial surge of cases. Education included both in person and virtual sessions along with real time ongoing support through provincial guidelines, videos, and other documents. Physician reported "stress level" pre- and post-Airway Lead support declined from a median score of 9 to 7 (on a 10-point Likert Scale).
\end{abstract}

Keywords Emergency medicine $\cdot$ Airway leads $\cdot$ COVID-19

\section{Résumé}

Le premier cas de COVID-19 ayant été confirmé au Canada au début de 2020, notre pays s'est joint à la lutte contre un nouveau pathogène dans une pandémie mondiale. Le stress de l'incertitude et du changement de pratique était plus évident au service d'urgence lorsqu'il s'agissait de gérer les patients connus ou soupçonnés de la COVID-19 qui avaient besoin d'une prise en charge des voies respiratoires. Reconnaissant la nécessité d'une approche coordonnée, un modèle de développement professionnel continu distribué à l'échelle de la province pour la gestion des voies aériennes a été élaboré en utilisant les Airway Leads pour aider à préparer le personnel médical de première ligne qui assure la gestion des voies aériennes de ces patients. Airway Leads a travaillé avec les médecins locaux pour dispenser un enseignement cohérent et de haute qualité sur les voies aériennes dans toute la province lors de l'augmentation initiale du nombre de cas. L'éducation comprenait à la fois des sessions en personne et virtuelles ainsi qu'un soutien continu en temps réel par le biais de directives provinciales, de vidéos et d'autres documents. Le "niveau de stress" déclaré par le médecin avant et après l'intervention de Airway Lead a diminué, passant d'un score médian de 9 à 7 (sur une échelle de Likert de 10 points).

\section{Background}

In early 2020, the first case of COVID-19 was confirmed in Canada [1]. Guided by international reports, provincial healthcare systems began preparing for an influx of criti-

Adam Harris

adam.harris@dal.ca

1 Emergency Medicine Dalhousie University, 3rd Floor, HI Site, Suite 355, Room 364D, 1796 Summer Street, Halifax, NS B3H 3A7, Canada

2 Dalhousie University, HI Site, 3rd FloorSuite 355, Room 364D, 1796 Summer Street, Halifax, NS B3H 3A7, Canada cally ill patients requiring intubation and mechanical ventilation [2]. The severity of respiratory illness being reported, combined with the risk of virus transmission to health-care providers during aerosol-generating medical procedures [3], created an urgent need for airway education as several 
standard aspects of airway management were required to change [4].

\section{Rationale}

Clinicians were faced with the difficult task of balancing pre COVID-19 optimal patient care strategies with the health and safety of their clinical teams [3-6]. Airway interventions and therapies commonplace in the emergency department (ED) only weeks prior, were now being reconsidered with respect to their efficacy and safety profile [3-6]. Clinicians were challenged to provide a skillful approach to intubation with a high first pass success rate in hypoxemic, apnea-intolerant patients without the use of conventional active preoxygenation approaches-all while utilizing a higher level of personal protective equipment.

The Nova Scotia Health Authority (NSHA) comprises four regional health zones collectively caring for nearly one million people. Provincial COVID-19 airway management guidelines were developed to provide a safe standardized approach to airway management [7]. During the early days of the COVID-19 outbreak, guidelines for airway management were changing rapidly based on evolving Level C observational evidence, expert opinion, and the experiences of others from "hot zones" around the world. The goal of this rapid response continuing professional development intervention was to disseminate the provincially endorsed airway guidelines and support their implementation at the local level.

\section{Description of the innovation}

Four Airway Leads were recruited to develop and deliver content to each NSHA zone. Airway Leads were emergency physicians with additional expertise in airway management, medical education and procedural skill teaching. All Airway Leads were Airway Interventions \& Management in Emergencies (AIME) certified instructors and received additional COVID-19 education training. Airway Leads liaised with emergency leadership in each zone to curate, design and distribute educational materials developed by provincial airway experts.

Four days after program inception, the first COVID19 education session was delivered on site. Sessions were designed for emergency physicians, nurses, paramedics, and respiratory therapists working in the ED. Physicians from other acute-care specialties (i.e., anesthesia, critical care) were also welcomed to attend. Airway Leads initially travelled to regional and tertiary care hospitals within their zone to conduct education sessions. While $>85 \%$ of initial sessions were conducted in person, travel to hospitals was halted by an increase in COVID-19 prevalence prior to all sites being visited. Airway Leads shifted to providing education sessions through videoconferencing. Education sessions were simultaneously facilitated remotely by Airway Leads and on site by local clinicians. Follow up simulation sessions were then organized independentaly by locally established teams, using a "train the trainer" model and utilizing the Airway Lead as a consultant if required. Subsequent on-site simulation session availability varied across the province and was left to each hospital to determine based on their needs. Each site determined the composition of their own COVID-19 airway teams based on available local expertise.

As guidelines for airway management of the COVID-19 patient evolved, Airway Leads would provide follow up educational resources highlighting the key practice changes. In addition, questions brought forward by specific sites were discussed as a group prior to response, as the same scenarios had often been reviewed at other sites. Resources were distributed through an open access educational website and updated to reflect evolving evidence [8]. Support materials included locally developed airway checklists, intubation 'kitdump' maps, procedural approach videos, and the provincial COVID-19 airway management guidelines. Provincial ED airway grand rounds were delivered virtually four weeks following the first provincial case. This allowed time for feedback from local EDs after the initial on site / virtual visits to ensure consistency of messaging across the province (Fig. 1).

\section{Discussion}

The pace and extent at which clinical practice has changed on the basis of Level $\mathrm{C}$ evidence has been unprecedented. Practice changing recommendations required adaptation, adoption and dissemination of materials that may have, in other times, been considered premature for lack of highquality evidence. Airway Leads utilized previously existing International Airway working groups and forums, telephone and email correspondence with physicians in hot zones, and thorough review of emerging literature and consensus guideline documents to evaluate and adapt the content of education. The concept of "Airway Leads" and "Airway Groups" has been supported by the Difficult Airway Society since 1996, and this is a good example of its application at the provincial level, aimed at improving airway management from the perspectives of anatomy, physiology, logistics, and education [9].

Difficulty in the evaluation of the effectiveness of broad airway quality initiatives has been previously recognized [9]. Within days of announcing this provincial initiative, the first on site education session occurred. Therefore, a preintervention evaluation was not performed. Following the 


\section{COVID-19 AIRWAY MANAGEMENT TIMELINE IN} NOVA SCOTIA EMERGENCY DEPARTMENTS

\section{Managing and Disseminating Change Ahead of the Initial Surge}

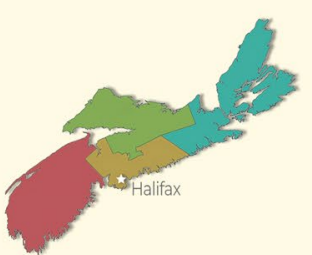

Province divided into four zones

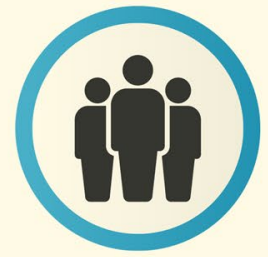

Each zone with dedicated airway lead

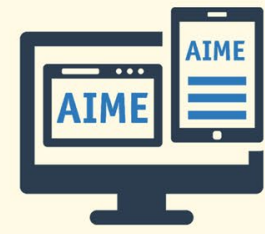

Materials available in person and online
December, 2019

First cases of COVID-19 reported

in Wuhan, China

March 1, 2020

First case in New York

March 11, 2020

Pandemic declared by WHO.

Provincial airway equipment upgrades for EDs initiated

March 15, 2020

First case in Nova Scotia

March 17, 2020

Nova Scotia's EM Airway Leads begin on-site and remote education for provincial EDs

March 22, 2020

Version 2.0 Nova Scotia ED

COVID-19 Provincial Airway Guidelines

April 16, 2020

Provincial Airway Grand Rounds
January 31, 2020

First case in Italy

March 10, 2020

Nova Scotia institutes a provincial

Airway Lead Mandate to distribute

educational materials to each zone

March 12, 2020

Version 1.0 Nova Scotia ED

COVID-19 Provincial Airway Guidelines

March 16, 2020

Safe Airway Society Guidelines published

March 20, 2020

First COVID-19 intubation in Nova Scotia

March 30, 2020

Version 3.0 Nova Scotia ED

COVID-19 Provincial Airway Guidelines

May 29, 2020

First day of zero new cases in Nova Scotia

Fig. 1 Infographic 
first surge of COVID-19 cases in the province, an evaluation using the web-based survey tool Opinio was sent to ED site leads to determine the usefulness of each of the interventions. Amongst physicians in their ED (our target audience for education), the perceived "stress level" pre- and postAirway Lead support as evaluated by their site lead dropped from a median of 9 to 7 (on a 10-point Likert Scale). In allied health care providers the drop was from 8 to 7.5. ED site leads reported educational interventions as having a "high impact" on preparing their teams with median scores of 8.5-9.5/10, and the majority felt that repeating interventions such as site visits, online provincial rounds, and email/ telephone support would be very useful in the setting of another surge of COVID-19 cases.

The use of Airway Leads for the delivery of a rapid response distributed model of continuing professional development allowed for the preparation of a large number of front-line medical personnel to safely provide ED airway management for patients with known or suspected COVID19. The interventions by the Airway Leads led to an overall reduction in COVID-19 related stress amongst physicians but not allied health care providers. Involving members from this group in the development and implementation of future interventions may improve the impact.

\section{Summary}

A rapid response distributed model of continuing professional development was developed to help support emergency department teams in the optimization of airway management for patients with known or suspected COVID19. Using geographic Airway Leads as a support network, provincially developed airway management recommendations were disseminated, implemented, and where necessary adapted to meet local needs and resources.

\section{Compliance with ethical standards}

Conflict of interest The authors declare no conflict of interest with the publication of this paper.

\section{Reference}

1. Marchand-Senécal X, Kozak R, Mubareka S, et al. Diagnosis and management of first case of COVID-19 in Canada: lessons applied from SARS. Clin Infect Dis. 2020. https://doi.org/10.1093/cid/ ciaa227 ((published online ahead of print, 2020 Mar 9)).

2. Yao W, Wang T, Jiang B, et al. Emergency tracheal intubation in 202 patients with COVID-19 in Wuhan, China: lessons learnt and international expert recommendations. Br J Anaesth. 2020. https ://doi.org/10.1016/j.bja.2020.03.026 ((published online ahead of print, $2020 \mathrm{Apr} 10$ )).

3. El-Boghdadly K, Wong DJN, Owen R, et al. Risks to healthcare workers following tracheal intubation of patients with COVID-19: a prospective international multicentre cohort study. Anaesthesia. 2020. https://doi.org/10.1111/anae.15170 ((published online ahead of print, $2020 \mathrm{Jun} 9$ )).

4. Lockhart SL, Duggan LV, Wax RS, Saad S, Grocott HP. Personal protective equipment (PPE) for both anesthesiologists and other airway managers: principles and practice during the COVID-19 pandemic [published online ahead of print, 200 Apr 23] Équipements de protection individuelle (EPI) pour anesthésiologistes et autre personnel en charge des voies aériennes: principes et pratiques pendant la pandémie de COVID-19[published online ahead of print, 2020 Apr 23]. Can J Anaesth. 2020. https://doi. org/10.1007/s12630-020-01673-w.

5. Alhazzani W, Møller MH, Arabi YM, et al. Surviving Sepsis Campaign: guidelines on the management of critically ill adults with Coronavirus Disease 2019 (COVID-19). Intensive Care Med. 2020;46(5):854-87. https://doi.org/10.1007/s00134-020-06022-5.

6. Kovacs G, Sowers N, Campbell S, French J, Atkinson P. Just the Facts: Airway management during the coronavirus disease 2019 (COVID-19) pandemic. CJEM. 2020. https://doi.org/10.1017/ cem.2020.353 ((published online ahead of print, 2020 Mar 30)).

7. Kovacs, G, Law, JA, Witter, T. Airway Management Guidelines for Patients with Known or Suspected COVID-19 Infection. Nova Scotia Health Authority; 2020. https://policy.nshealth.ca/ Site_Published/covid19/document_render.aspx?documentRender. IdType $=6 \&$ documentRender.GenericField $=\&$ documentRender. $\mathrm{Id}=76497$. Accessed 1June 2020.

8. AIME. Airway Interventions \& Management in Emergencies. https://www.aimeairway.ca. Accessed 1 June 2020.

9. McNarry AF, Cook M, T, Baker PA, O'Sullivan EP, . The Airway Lead: opportunities to improve institutional and personal preparedness for airway management. Br J Anaesth. 2020. https ://doi.org/10.1016/j.bja.2020.04.053 ((published online ahead of print, 2020 Apr 27)). 